\title{
Features of Production of Fine Concretes Based on Clinkerless Binders of Alkaline Mixing
}

\author{
M. Salamanova ${ }^{1,2(\bowtie)}$, S.-A. Murtazaev ${ }^{1,2,3}$, A. Alashanov ${ }^{1}$, \\ and Z. Ismailova ${ }^{1}$ \\ ${ }^{1}$ Grozny State Oil Technical University named after Academician \\ M.D. Millionshchikov, Grozny, Russia \\ Madina_salamanova@mail.ru \\ 2 Complex Research Institute named after H.I. Ibragimov, \\ Russian Academy of Sciences, Grozny, Russia \\ 3 Academy of Sciences of the Chechen Republic, Grozny, Russia
}

\begin{abstract}
The paper showed relevance and potential for the development of clinkerless alkaline activation, since at the present the production of currently leading "constructional" binder, Portland cement, has been increasing, and carbon dioxide released during cement production has a negative effect on the ecological situation of separate countries and the whole world. The world community has long been concerned about the problem of switching to clinkerless binders and building composites to replace resource-intensive cement, at least in those areas of construction that do not need its high technical and functional properties. We gave formulations and properties of clinkerless alkaline activation based on highly dispersed mineral components, effective compositions of fine concretes based on the use of the proposed clinkerless alkaline activation cements were obtained. It was theoretically substantiated and practically proved that Brønsted acid sites on the surface of highly active powders accelerated synthesizing silica gel, supported polymerization of silicon-oxygen anions, enhanced ion exchange reactions and stabilized intergranular contact formation.
\end{abstract}

Keywords: Portland cement - Clinkerless binders - Mineral powders · Alkaline mixer $\cdot$ Liquid glass $\cdot$ High dispersion

\section{Introduction}

The environmental problem, created by the cement industry, is associated with consumption of large volumes of raw materials and release of huge amounts of carbon dioxide and dust during production of mineral binders into the atmosphere. A promising direction for solving this problem is the use of alkaline activation binders, which can be produced both from wastes of the fuel and energy industry, if present in the region, and using highly dispersed aluminosilicate additives, which chemical composition is characterized by an increased content of aluminum and silicon (Nikiforov et al. 2011; Salamanova et al. 2015; Strokova et al. 2013). 


\section{Methods and Materials}

This paper presents results of researches on the formulation and study of the properties of alkaline mixing binders using of sedimentary and magmatic rocks: quartz sand, limestone, volcanic tuff and silicified marl.

\section{Results and Discussion}

To prepare highly dispersed powders from the studied rocks, they were preliminarily crushed in a jaw crusher, and then subjected to fine grinding for $1 \mathrm{~h}$ in a vibratory ball mill.

At the next stage, a number of Bronsted active crystallization centers on the surface of the mineral powder was studied by the method (Strokova et al. 2013) of determining the exchange capacity with respect to calcium ions (Table 1).

Table 1. Surface activity of fine powders

\begin{tabular}{l|l|l|l|l|l}
\hline No. & Mineral powder & $\begin{array}{l}\text { Coefficient } \\
\text { of activity } \\
\text { Ka,\% }\end{array}$ & $\begin{array}{l}\text { Coefficient of } \\
\text { hydraulic } \\
\text { activity } \mathrm{G}_{\mathrm{HD}}\end{array}$ & $\begin{array}{l}\text { Number of active } \\
\text { centers of } \\
\text { crystallization, } \\
\mathrm{mg} \text { eq/g }\end{array}$ & $\begin{array}{l}\text { Specific } \\
\text { surface of } \\
\text { powders, } \mathrm{m}^{2} / \\
\mathrm{kg}\end{array}$ \\
\hline 1 & Quartz sand (QS) & 22 & 1,76 & 21 & 810 \\
\hline 2 & $\begin{array}{l}\text { Volcanic Tuff } \\
(\text { VT) }\end{array}$ & 37 & 1,90 & 34 & 905 \\
\hline 3 & Limestone (L) & 8 & 1,24 & 12 & 1060 \\
\hline 4 & $\begin{array}{l}\text { Thermo- } \\
\text { activated marl } \\
\text { (TM) at } 700{ }^{\circ} \mathrm{C}\end{array}$ & 62 & 2,03 & 42 & 1150 \\
\hline 5 & Sandstone (S) & 10 & 1,44 & 16 & 1020 \\
\hline
\end{tabular}

The coefficient of activity Ka,\% The coefficient of hydraulic activity GAMD The number of active centers of crystallization, $\mathrm{mg} \mathrm{eq} / \mathrm{g}$ Specific surface of powders, $\mathrm{m}^{2} / \mathrm{kg}$.

Thus, analyzing the results obtained we can state that the activity coefficients, including the number of active crystallization centers, largely depend on the degree of disclosure of defects formed during their grinding, in combination, all this contributes to an increase in the reactivity of the powders used in concrete as highly dispersed additives.

After confirming the reactivity of the proposed powders, samples of $10 \mathrm{~cm}$ in size were prepared using the mixture: a highly dispersed component, fractionated sand, obtained by mixing in a ratio of 55:45\% of screening crushing of rocks of the Argun field and fine sand of the Chervlensky field. The mixing was carried out with liquid glass, sodium hydroxide and accelerator of the precipitation of silica gel with sodium fluoride in specified proportions. The prepared samples were hard in normal conditions at a temperature of $20 \pm 2{ }^{\circ} \mathrm{C}$, but after 2 days the samples were placed in an oven at a 
temperature of $40-50{ }^{\circ} \mathrm{C}$ for several days. The test results of the investigated finegrained concretes based on alkaline activation binders are shown in Table 2.

Table 2. Properties of fine concrete based on clinkerless binders of alkaline activation

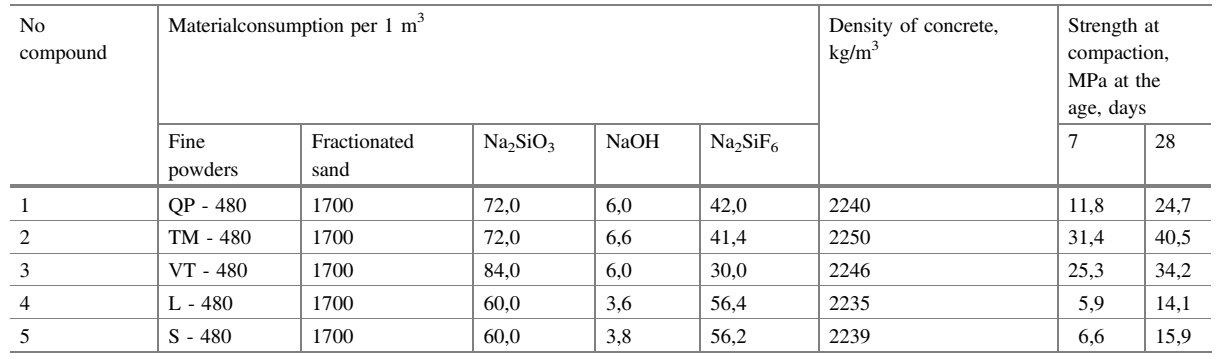

Note: QP - quartz powder; TM - thermo-activated marl at $7000{ }^{\circ} \mathrm{C}$; VT - volcanic tuff; L - limestone flour; $\mathrm{S}$ - sandstone; $\mathrm{Na}_{2} \mathrm{SiO} \mathrm{O}_{3}-\mathrm{sodium}$ liquid glass; $\mathrm{Na}_{2} \mathrm{SiF}_{6}$ - sodium silicofluoride; $\mathrm{NaOH}$ - sodium hydroxide.

The alkaline activation binder with the use of fine powders of thermally activated marl showed the best results, so these particular samples of concrete were examined by Quanta 3D scanning electron microscope (Fig. 1).
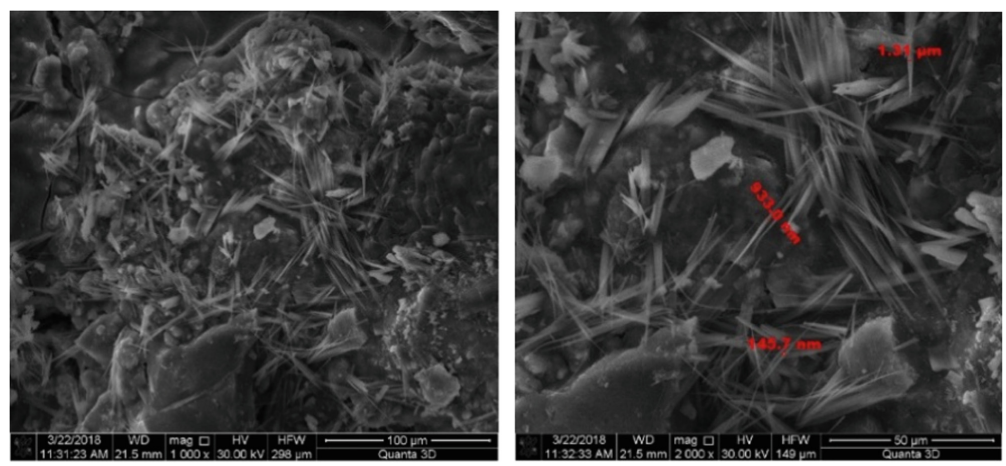

Fig. 1. Micrographs of concrete on thermo-activated alkali activated marl

In the contact area we determined a fairly strong accretion of particles of binder and quartz sand, no defects on the surface in the form of growths or cracks, irregularities of various shapes and sizes, and that individual particles have a needle-fibrous, vitreous structure, which indicated an increased binder activity.

High strength results of fine concrete using clinkerless alkaline mixing on the basis of thermally activated marl are explained by formation of a durable geopolymer stone, represented by a frame aluminosilicate shutter alkaline medium with the formation of a 3D aluminosilicate hydrogel (Murtazaev and Salamanova 2018; Soldatov et al. 2016). 


\section{Conclusions}

Thus, we theoretically justified and practically proved that Brønsted acid sites on the surface of highly active powders accelerated process of synthesizing silica gel, promoted the polymerization of silicon-oxygen anions, enhanced ion exchange reactions and stabilized intergranular contact formation.

The results of the researches significantly expanded the field of application of clinkerless binders on a liquid-glass binder and might enable partial replacement of expensive and energy-intensive portland cement in the construction industry.

\section{References}

Murtazaev S-A, Salamanova M (2018) Prospects for the use of thermoactivated raw materials of aluminosilicate nature. Volga Sci J 46(2):65-70

Nikiforov EA, Loganina VI, Simonov EE (2011) The influence of alkaline activation on the structure and properties of diatomite. Bull BSTU Named After V.G. Shukhov (2):30-32

Salamanova MSh, Saidumov MS, Murtazaeva TS-A, Khubaev MS-M (2015) High-quality modified concretes based on mineral additives and superplasticizers of various nature. Sci Anal Mag "Innov Invest" (8):159-163

Soldatov AA, Sariev IV, Zharov MA, Abduraimova MA (2016) Building materials based on liquid glass. In: The collection: actual problems of construction, transport, engineering and technosphere safety materials of the IV-th annual scientific-practical conference of the NorthCaucasian Federal University. N.I. Stoyanov (executive editor), pp 192-195

Strokova VV, Zhernovskiy IV, Maksakov AV (2013) Express-method for determining the activity of silica raw material for production, granulated nanostructuring aggregate. Constr Mater (1):38-39

Open Access This chapter is licensed under the terms of the Creative Commons Attribution 4.0 International License (http://creativecommons.org/licenses/by/4.0/), which permits use, sharing, adaptation, distribution and reproduction in any medium or format, as long as you give appropriate credit to the original author(s) and the source, provide a link to the Creative Commons license and indicate if changes were made.

The images or other third party material in this chapter are included in the chapter's Creative Commons license, unless indicated otherwise in a credit line to the material. If material is not included in the chapter's Creative Commons license and your intended use is not permitted by statutory regulation or exceeds the permitted use, you will need to obtain permission directly from the copyright holder.

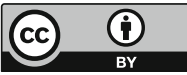

